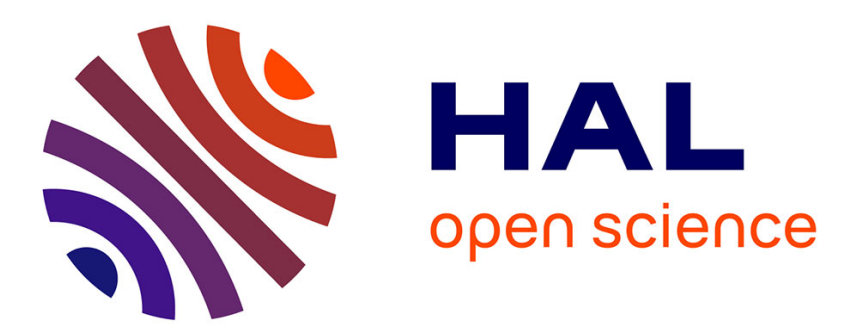

\title{
Archaeometrical study of Khmer stoneware from the Angkorian period: Results from the Cerangkor Project
}

\author{
Valérie V. Thirion-Merle, G. Thierrin-michael, A. Desbat
}

\section{To cite this version:}

Valérie V. Thirion-Merle, G. Thierrin-michael, A. Desbat. Archaeometrical study of Khmer stoneware from the Angkorian period: Results from the Cerangkor Project. Archaeometry, 2019, 61 (6), pp.12461263. 10.1111/arcm.12483 . hal-03508108

\section{HAL Id: hal-03508108 \\ https://hal.science/hal-03508108}

Submitted on 19 Jan 2022

HAL is a multi-disciplinary open access archive for the deposit and dissemination of scientific research documents, whether they are published or not. The documents may come from teaching and research institutions in France or abroad, or from public or private research centers.
L'archive ouverte pluridisciplinaire HAL, est destinée au dépôt et à la diffusion de documents scientifiques de niveau recherche, publiés ou non, émanant des établissements d'enseignement et de recherche français ou étrangers, des laboratoires publics ou privés. 


\title{
ARCHAEOMETRICAL STUDY OF KHMER STONEWARE FROM THE ANGKORIAN PERIOD: RESULTS FROM THE CERA NGKOR PROJECT*
}

\author{
V. THIRION-MERLE† \\ CNRS, UMR ArAr Archaeology and Archaeometry, Maison de l'Orient et de la Méditerranée, Université \\ Lyon 2, 7 rue Raulin F-69365 Lyon cedex 7, France \\ G. THIERRIN-MICHAEL \\ Department of Geosciences, University of Fribourg, Chemin du Musée 6 CH-1700 Fribourg, Switzerland \\ and A. DESBAT \\ CNRS, UMR ArAr Archaeology and Archaeometry, Maison de l'Orient et de la Méditerranée, Université \\ Lyon 2, 7 rue Raulin F-69365 Lyon cedex 7, France
}

\begin{abstract}
In the area around Angkor, Cambodia, several ceramics kilns dating from the ninth to 15th centuries CE have been discovered since 1995. The technical, typological and compositional characterization of their production has been one of the main goals of the Cerangkor Project. Samples of green-glazed 'Kulen-type' stoneware and non-glazed stoneware produced in five kiln sites in the Angkor region were analysed chemically by wavelength-dispersive X-ray fluorescence spectrometry (WDS-XRF) and also petrographically. The data indicate that some workshops used similar raw materials for the same types of ceramics, suggesting the exploitation of the same geological formations in the whole region. Several references groups were established for each type of stoneware offering an important database for future provenance studies of sherds from consumption sites.
\end{abstract}

\section{KEYWORDS: CERAMICS, KHMER STONEWARE, CAMBODIA, ANGKOR, X-RAY FLUORESCENCE SPECTROMETRY, PETROGRAPHY, REFERENCE GROUPS}

\section{INTRODUCTION}

Glazed stonewares are a typical production of the Angkorian period, which began at the end of the ninth century CE and lasted probably to the end of the 14th century CE. For more than 30 years, the studies of Khmer stoneware followed the lead of the pioneering work of $\mathrm{B}$. Ph. Groslier, who published the first synthesis in 1981. His work, widely based on his excavations of different sites, notably at the Royal Palace of Angkor, and at the burial site of Srah Srang (Groslier 1954, 1964; Courbin 1988), described the evolution of Khmer stoneware, but failed to include kiln sites.

The archaeometrical study of Khmer stoneware in the present paper was carried out from 2008 as part of the Cerangkor Project. Created in 2008, this project is a collaborative research programme with the French Centre National de la Recherche Scientifique (CNRS-National Scientific Research Centre), the EFEO (Ecole Française d'Extrême Orient) Centre (French School of

\footnotetext{
*Received 24 May 2018; accepted 3 April 2019

$\dagger$ Corresponding author: email valerie.merle@mom.fr

(C) 2019 University of Oxford
} 
Asian Studies) in Siem Reap, Cambodia, and the APSARA Authority (the Authority for the Protection and Management of Angkor and the Region of Siem Reap) with funding from the French Ministry of Foreign Affairs (Desbat et al. 2008, 2009, 2010, 2011, 2012, 2013, 2014, 2015; Pottier and Desbat 2016, 2017). It was developed to investigate the ceramics produced at the kiln sites in the region of the ancient Khmer capital of Angkor, in the period between the ninth and the 15 th centuries. Research was designed to develop a characterization based on a combination of typology (technical styles) and chemical composition of the pottery. No programme of this breadth and extent has ever been undertaken, since typological and chemical compositional analyses of Angkorian stoneware were limited to a few case studies (Ea 2009, 2010; Yamamoto 2011).

\section{KILNS CONTEXT AND SAMPLE COLLECTION}

Despite the discovery of a large kiln site on Phnom Kulen, near the village of Anlong Thom at the end of the 19th century (Aymonier 1901), Khmer stoneware kiln sites have only recently been the subject of scientific studies. For a long time, the Phnom Kulen kiln site was the only one known. However, between 1995 and 2000, the discovery of several kilns around Angkor has shown that there were at least four other production sites in the Angkorian area (Ea 2009, 2010) (see Fig. 4 for the precise location of these kiln sites of the Angkor region):

- Tani includes more than 20 kilns divided into five groups that produced glazed and unglazed stoneware.

- Khnar Po comprises nearly 30 kilns, forming four groups, that produced glazed and unglazed stoneware.

- Sor Sei, at the foot of the Phnom Kulen, also includes about 30 kilns divided into three groups that produced glazed and unglazed stoneware.

- Bankong, near Lolei, with more than 30 kilns, probably produced only unglazed stoneware. In 2007, a new group was discovered on the road connecting Angkor to the large provincial centre of Preah Khan of Kompong Sway, near Torp Chey (Hendrickson 2008). Furthermore, archaeologists discovered the two additional kiln sites of Veal Svay and Chong Samrong (Hein et al. 2013; Tabata et al. 2015). These three sites are located $60 \mathrm{~km}$ north-east of Siem Reap, and ceramics produced in these kilns are quite different from the Kulen stoneware and consist mainly of large brown-glazed jars.

In each site, some kilns have now been excavated by different scientific teams in collaboration with APSARA Authority. Archaeologists undertook the first study of the Tani kiln site beginning in 1996 and two kilns were excavated (Aoyagi et al. 2000; Aoyagi and Sasaki 2007). Two kilns were also excavated in the period 2006-07 at Thnal Mrech/Anlong Thom (Tabata and Chhay 2007; Miksic et al. 2008). A kiln from the A group was also excavated at the site of Sor Sei between 2005 and 2007 (Sugiyama 2008). A new excavation was conducted in 2015 on a kiln of the $\mathrm{C}$ group (Thmor Chul) (still unpublished). At Khnar Po, a first kiln was excavated and analysed in 2006 (Hirooka et al. 2009) and three others in 2015 (Marriner et al. 2018). Three kilns where partially excavated at the Bankong site in 2007 and 2009 (Miksic and Chhay 2010; Nakamura et al. 2011). Thanks to these excavations and prospections, the production of Kulen-type stoneware is relatively well known and several preliminary classifications have also been established both at the Anlong Thom site (Chhay et al. 2013 ) and at Sor Sei (Tin 2003).

In addition, archaeologists have undertaken excavations of kilns located north-east of Siem Reap: one at Torp Chey (Ea 2013), and the other two at Veal Svay (Tabata et al. 2015; Sugiyama et al. 2017) and Chong Samrong (Hein et al. 2013). 
For all kiln sites, radiocarbon analyses have provided dates that have recently been recalibrated and synthesized (Marriner et al. 2018). They confirm a late occupation of the Torp Chey group, dating to the 14th century, while the other kiln sites of Tani, Khnar Po, Bankong and Thnal Mrech reached the peak of their activity during the 11th and 12th centuries (Marriner et al. 2018, fig. 6). The sites of Bankong and Khnar Po appear to be occupied during an even earlier era, beginning in the late ninth to early 10th centuries.

The pottery samples discussed here were collected from the mentioned kiln sites during our own field prospections. A dozen clay and sand samples were taken from visible outcrops, either directly at the kiln sites or from locations situated within a $5 \mathrm{~km}$ radius around the kiln sites. All the analysed kiln sites are characterized by the presence of huge quantities of sherds distributed in distinct patterns across the settlements. For instance, at Thnal Mrech (near Anlong Thom village), the sherds are dispersed in the forest as well as concentrated in the partially excavated kiln structures as the result of looting (Desbat et al. 2008). In Tani, Sor Sei and Khnar Po, the ceramics are concentrated around the kiln remains, which take the form of mounds in the landscape (Desbat et al. 2008, 2009, 2010). In contrast, the dispersal zone of sherds around the kilns is larger at the site of Bankong (Desbat et al. 2008). As mentioned above, select kilns at each site were excavated before our survey (Aoyagi. et al. 2000; Aoyagi and Sasaki 2007; Tabata and Chhay 2007; Miksic et al. 2008; Ea 2010). At Khnar Po, several kilns were partly destroyed and cut at the level of the firing chamber during road works and field remodelling, and they were plainly visible during inspections between 2009 and 2013 (Desbat et al. 2009). At most kiln sites, several types of wares were present: green-glazed stoneware, unglazed stoneware as well as sherds initially considered earthenware. After the typological study and establishment of a repertory of forms by type of stoneware, we realized that the so-called 'earthenware' sherds did not form a separate category. They all had shapes strictly identical to the unglazed stoneware. In other words, the misidentified 'earthenwares' probably failed to become sintered due to their positioning in the kilns that lacked the requisite high temperatures. Therefore, they should now be considered underfired stoneware vessels rather than earthenware.

A particular feature of the assemblage of Thnal Mrech is the presence of brown-glazed stoneware coexisting with green-glazed and rare unglazed stoneware (Desbat et al. 2008). We selected representative samples of these different types of stoneware for analyses.

\section{GOALS AND METHODS}

The main goal of the archaeometrical research was the creation of a reference database for future provenance studies. This entailed characterizing kiln productions chemically and petrographically, as well as attempting to differentiate the workshops. The study also aimed to increase our knowledge about technological issues such as the choice of raw materials and ceramic paste preparation in order to answer the following questions:

- What kind of clay(s) was/were used?

- Is it possible to identify the location of the clay resources?

- How was clay prepared (washing/levigating, mixing with sand or mixing of several clays, differences between wares, etc.)?

Two analytical methods were combined: chemical and petrographic analyses. Chemical analysis was carried out by wavelength-dispersive X-ray fluorescence spectrometry (WDS-XRF), in the Archaeometry and Archaeology Laboratory in Lyon (France), using a Bruker S8 Tiger spectrometer with a Rh excitation source. Samples of generally $2 \mathrm{~g}$, a minimum of $1 \mathrm{~g}$, are cut out with a diamond-coated saw (the minimum quantity of $1 \mathrm{~g} / \mathrm{sample}$ was fixed in accordance with 
several other laboratories as a compromise between the representativity of the analysed portion with respect to the ceramic and the destruction of the sherd; Maggetti et al. 1981). The external surfaces, liable to chemical alteration during burial, and all traces of glazes or slips are removed. Heating the samples at $950^{\circ} \mathrm{C}$ (necessary to remove water, volatiles and organics) is followed by cooling and grinding with a tungsten-carbide ball mill. A total of $800 \mathrm{mg}$ of powdered sample is then mixed with $3200 \mathrm{mg}$ of flux (lithium metaborate and tetraborate) and the resultant mix is heated and fused to produce a glass disc. The measurement can then be performed on this glass disc of homogenous composition, which corresponds to a mean chemical composition representative of the initial material. Indeed, this procedure provides the bulk chemical composition of the ceramic (matrix plus inclusions) and consequently of the material used for its manufacture (Thirion-Merle 2014; Waksman 2014). For each sample, 24 components were determined based on calibration curves established with 40 international geostandards (Centre de Recherches Pétrographiques et Géochimiques (CRPG), United States Geological Survey (USGS), National Institute of Standards and Technology (NIST), British Chemical Standards, etc.).

We applied several uni-, bi- and multivariate statistical data treatments to interpret the chemical results. Among the multivariate methods used, we present here the results mainly from hierarchical clustering analysis, applied to reduced centred data, using Euclidian distance and average linkage (Picon 1984; Baxter 1994). In our case, the calculations are carried out on 16 of the 24 determined chemical components: eight major and minor elements in ceramics (magnesium oxide $(\mathrm{MgO})$, alumina $\left(\mathrm{Al}_{2} \mathrm{O}_{3}\right)$, silica $\left(\mathrm{SiO}_{2}\right)$, potassium oxide $\left(\mathrm{K}_{2} \mathrm{O}\right)$, calcium oxide $(\mathrm{CaO})$, titanium oxide $\left(\mathrm{TiO}_{2}\right)$, manganese oxide $(\mathrm{MnO})$ and iron oxide $\left.\left(\mathrm{Fe}_{2} \mathrm{O}_{3}\right)\right)$, and eight trace elements of various geochemical behaviour (vanadium $(\mathrm{V})$, chrome $(\mathrm{Cr})$, nickel $(\mathrm{Ni})$, rubidium $(\mathrm{Rb})$, strontium $(\mathrm{Sr})$, zirconium $(\mathrm{Zr})$, baryum $(\mathrm{Ba})$ and cerium $(\mathrm{Ce}))$. Phosphorus oxide $\left(\mathrm{P}_{2} \mathrm{O}_{5}\right)$, zinc $(\mathrm{Zn})$, lead $(\mathrm{Pb})$ and copper $(\mathrm{Cu})$ were not considered for classification since they are indicative of possible pollution problems. Lanthanum (La), yttrium (Y) and thorium (Th) lack relevance for the comparison, and measurement of sodium oxide $\left(\mathrm{Na}_{2} \mathrm{O}\right)$ is below the quantitative limit of our spectrometer. In the resulting dendrogram (e.g., Fig. 3, b), each sample is represented as a vertical bar at the base of the figure and the two samples closest in composition are joined by a horizontal link. The more similar the samples, the shorter the distance at which they are linked. The joined samples are then fused into a 'pseudo-sample' of average composition. Samples and pseudo-samples are then compared again, and fused by the same procedure. As samples become less similar, the level of linkage moves up the diagram until all the samples are connected. In the dendrogram, clusters of individuals of similar compositions are linked at lower levels, while clusters and samples connected at higher levels are less closely related. Thus, the hierarchical clustering analysis provides a classification method that enables one to identify groups of sherds with similar chemical compositions.

A total of 245 samples from the kiln sites were analysed chemically: 41 green-glazed stoneware, 10 brown-glazed stoneware and one clay from Thnal Mreck; 17 unglazed and 46 greenglazed stoneware from Tani; 19 unglazed and 27 green-glazed stoneware from Sor Sei; 21 unglazed and 42 green-glazed stoneware from Khnar Po; and 50 unglazed, 10 green-glazed sample and one clay from Bankong.

Petrographic analyses on thin sections under the polarizing microscope were applied to 42 of the 285 chemically analysed sherds, as well as to clay and sediment samples. The selected ceramic samples are representative of the different chemical compositional groups of each kiln site. This method reveals the nature, frequency and shape of the inclusions contained in the ceramics as well as the texture of the matrix. A slice about $3 \mathrm{~cm}$ long and $4 \mathrm{~mm}$ thick is cut through the sherd at right angles to the rim (and the throwing direction). This slice is then mounted on a glass slide and ground down to a standard thickness of $30 \mu \mathrm{m}$. 
RESULTS

\section{Comparison between wares}

Green-glazed and unglazed stoneware present quite different fabrics, which are easy to distinguish without microscopic enhancement (Fig. 1). Fabrics of the green-glazed ware are fine grained and generally light coloured, while the unglazed ceramics show coarser, orange to red fabrics with ferruginous nodules. These colour differences could be due to different iron content indicating different clay sources and/or to different firing atmospheres. The noted granulometric differences could indicate different clay sources or different preparations of basically the same clay. These issues are addressed by the following petrographic analyses.

Under the microscope, the two wares show very different grain size distributions. In the fine-grained fabric noted above, the matrix contains many very fine inclusions which are not visible to the naked eye, while the matrix in the coarser pottery is almost devoid of such fine grains (Fig. 1). This indicates clearly that the two types of wares are made from different clays, as this difference can result neither from levigating the coarser clay used for unglazed stoneware, nor from adding sand to the finer clay used for the green-glazed ware. Levigating or washing a coarse clay will diminish or eliminate the coarse fraction, but it will not add fine inclusions if they are not already present. Adding sand to a clay containing many fine inclusions will result in a coarse paste also rich in fine inclusions. The nature of the inclusions, however, consisting almost exclusively of grains of quartz, is the same in all analysed samples (Figure 1).

Chemically, green-glazed and unglazed wares from the same kiln site form two distinct groups clearly differentiated by several of the chemical components, as demonstrated by the comparison of two of the most discriminating components in Figure 2. While both wares possess typical stoneware compositions characterized by high silica $\left(\mathrm{SiO}_{2}\right)$ and alumina $\left(\mathrm{Al}_{2} \mathrm{O}_{3}\right)$ contents typical for clays rich in kaolinite (the chemical formula of which is $\left.\mathrm{Al}_{2} \mathrm{Si}_{2} \mathrm{O}_{5}(\mathrm{OH})_{4}\right)$, the unglazed ware always shows a higher contents of iron $\left(\mathrm{Fe}_{2} \mathrm{O}_{3}\right)$ (plus some of its correlated elements), as well as potassium $\left(\mathrm{K}_{2} \mathrm{O}\right)$ and correlated rubidium $(\mathrm{Rb})$. (See the average chemical composition of the different groups identified for each type of stoneware in Table 1, or the compositional data of the stoneware in Table S1.) These results clearly show that the potters have selected two different clay materials to produce green-glazed and unglazed stoneware.

In light of this discovery, the comparison between workshops is discussed below separately for each type of ware. We adopt a strategy that departs from the approach of earlier published investigations. They proposed differentiations to separate kiln sites that failed to take into account the categories of stoneware produced, that is unglazed, green-glazed and brown-glazed stoneware (Grave et al. 2017).

\section{Green-glazed stoneware}

The green-glazed stoneware of the so-called 'Kulen type' was produced at all five of the studied kiln sites (Tabata 2005; Ea 2009, 2010). Urns and boxes with lids with spectacularly elaborated designs, bottles and bowls are among the most important forms represented in the sample collection (Fig. 3, a) (Desbat et al. 2008, 2009, 2010, 2011, 2012). Chronologically, the earliest vessels come from the workshops of Khnar Po and Tani, which probably functioned from the ninth century onwards (Desbat 2011). Indeed, the green-glazed stoneware of these two kilns sites show the 

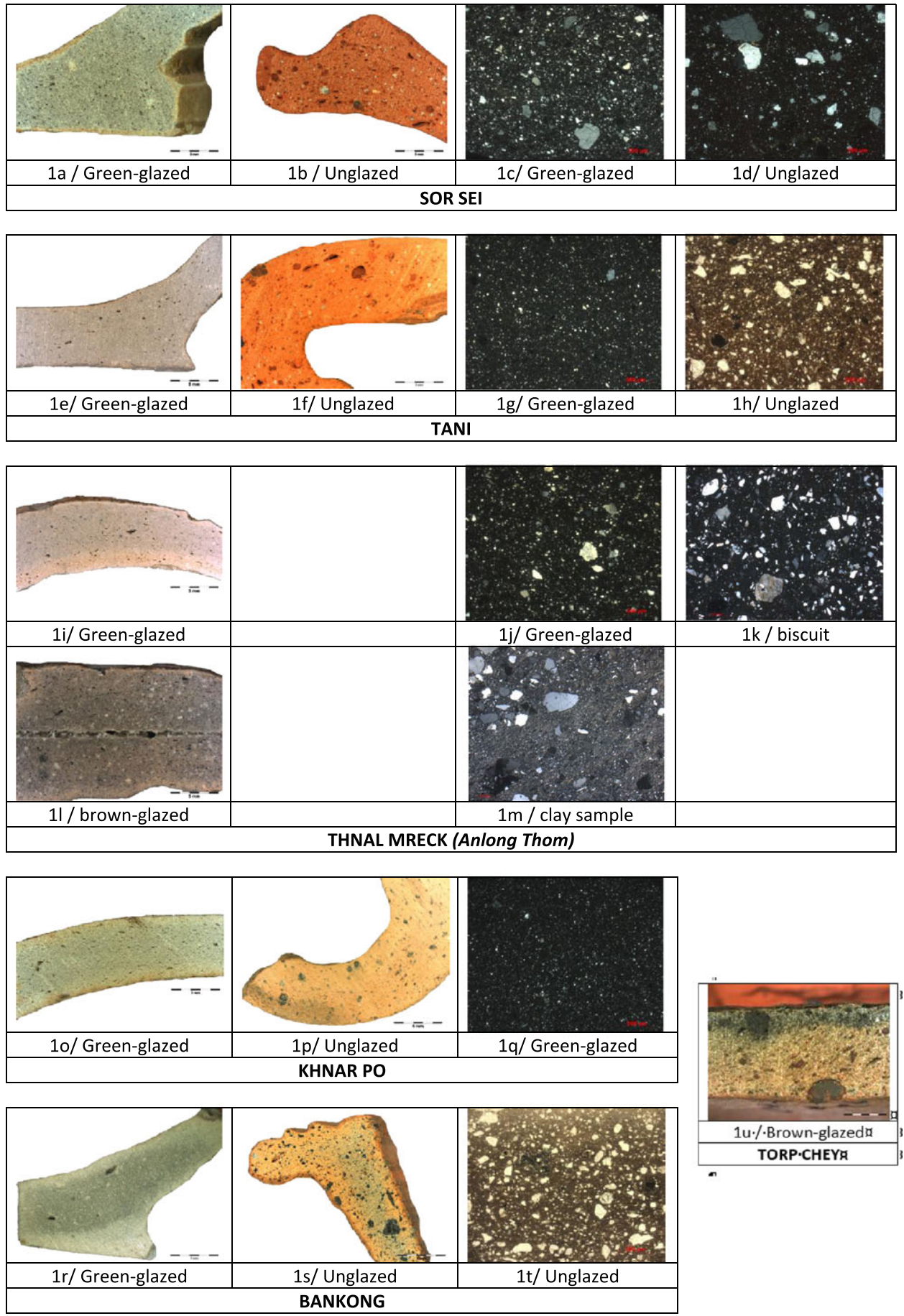

Figure 1 Fabrics of glazed and unglazed stoneware, as well as details of the clay sample KHM351 (1 m): macroscopic and microscopic views (crossed polarizing filters, except $1 \mathrm{~h}$ and $1 \mathrm{t}$; the same magnification is used for all details). [Colour figure can be viewed at wileyonlinelibrary.com] 


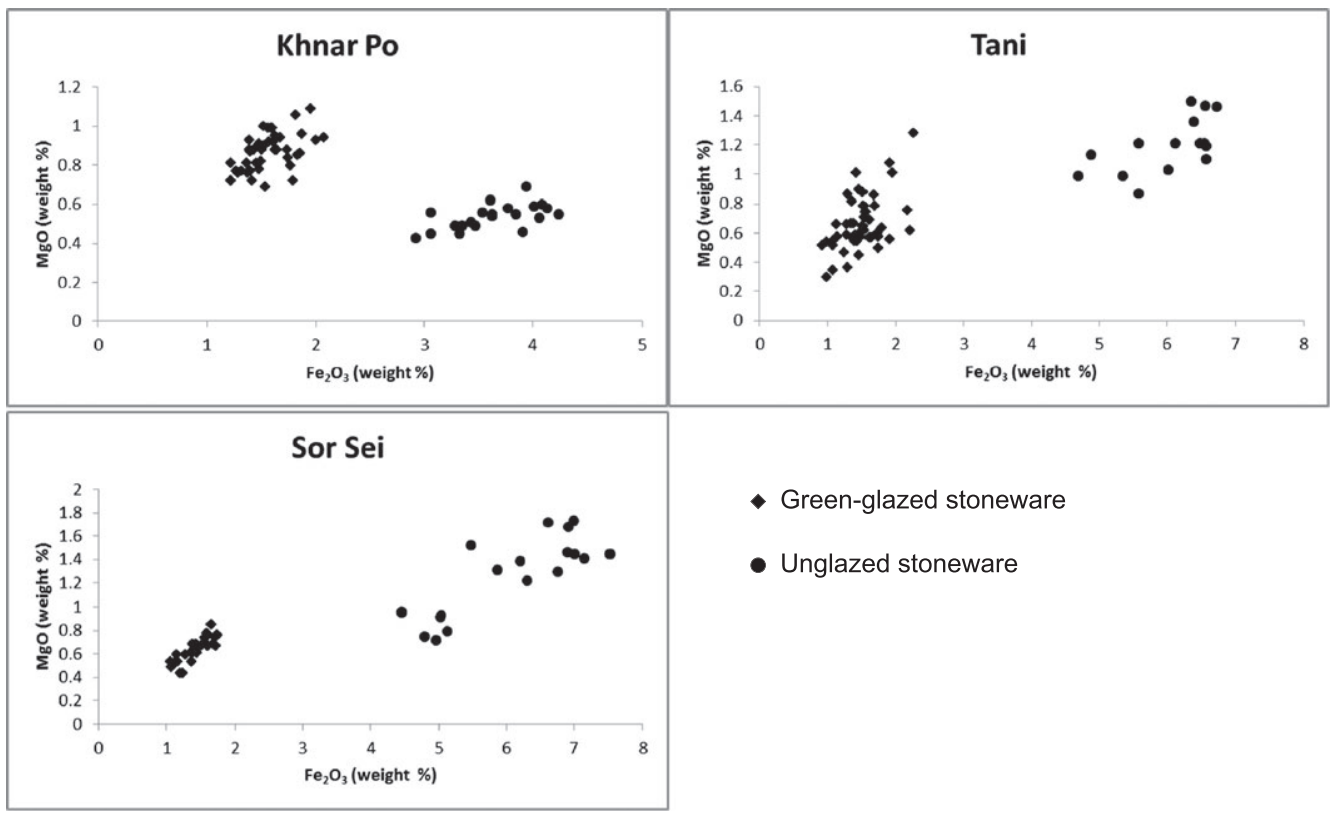

Figure 2 Binary plots of $\mathrm{MgO}$ versus $\mathrm{Fe}_{2} \mathrm{O}_{3}($ wt $\%$ ) with all analysed samples of green-glazed (diamonds) and unglazed stoneware (circles) for the three kiln sites.

same technical and typological characteristics as Kulen stoneware from early Angkorian archaeological contexts, including the temple of Bakong (Desbat 2007).

The chemical composition of this ware is characterized by high silica and alumina contents and very low contents of most other components (Table 1). This is typical of ceramics made of quite pure, white-firing kaolinitic clays. These common characteristics indicate that this type of clay was used in all five kiln sites to fabricate green-glazed stoneware. After having identified all the compositional groups produced at each kiln site, the question remained: Would it be possible to distinguish these ceramic productions further by their chemical compositions and/or petrography despite the similar raw material?

In order to classify the analyses and to test resemblances, multivariate statistical analysis was undertaken. The dendrogram of the cluster analysis shows that samples from one kiln site are not grouped strictly together (Fig. 3, b). The analyses are divided into two main groups, GGS1 and GGS2, with the first composed essentially of samples from Khnar Po and Tani and the second of samples from Sor Sei and Thnal Mrech. A subgroup from Thnal Mrech, chemically distinct from the main groups of this kiln site, clusters with the Khnar Po/Tani samples, while a subgroup from Tani is classed in the Sor Sei/Thnal Mrech group. The samples from Bankong are distributed over the two clusters.

This separation into two main groups is due to small differences in some chemical parameters: the wares of group 1 (GGS1) presenting higher levels of alumina, magnesia, titanium or potassium oxide (Table 1). We noted also small differences in some other components: vanadium, iron, rubidium and cerium (Fig. 3, c). From the cluster analysis, it became apparent that the samples from Bankong do not form a coherent group, which is also demonstrated in Figure 3 (c), where the points representing pottery from that site scatter over the entire variation field occupied 
Archaeometrical study of Khmer stoneware from the Angkorian period

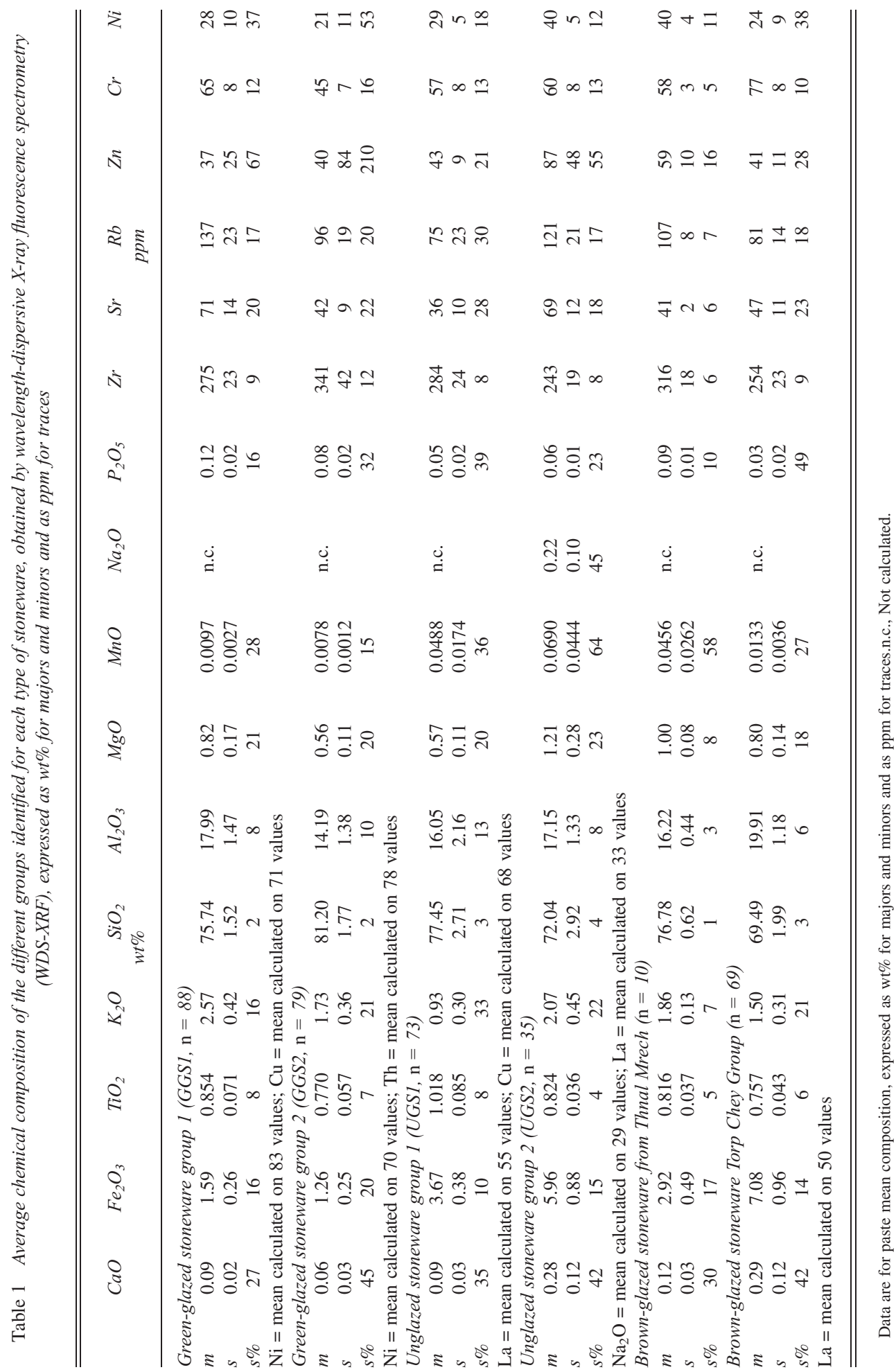




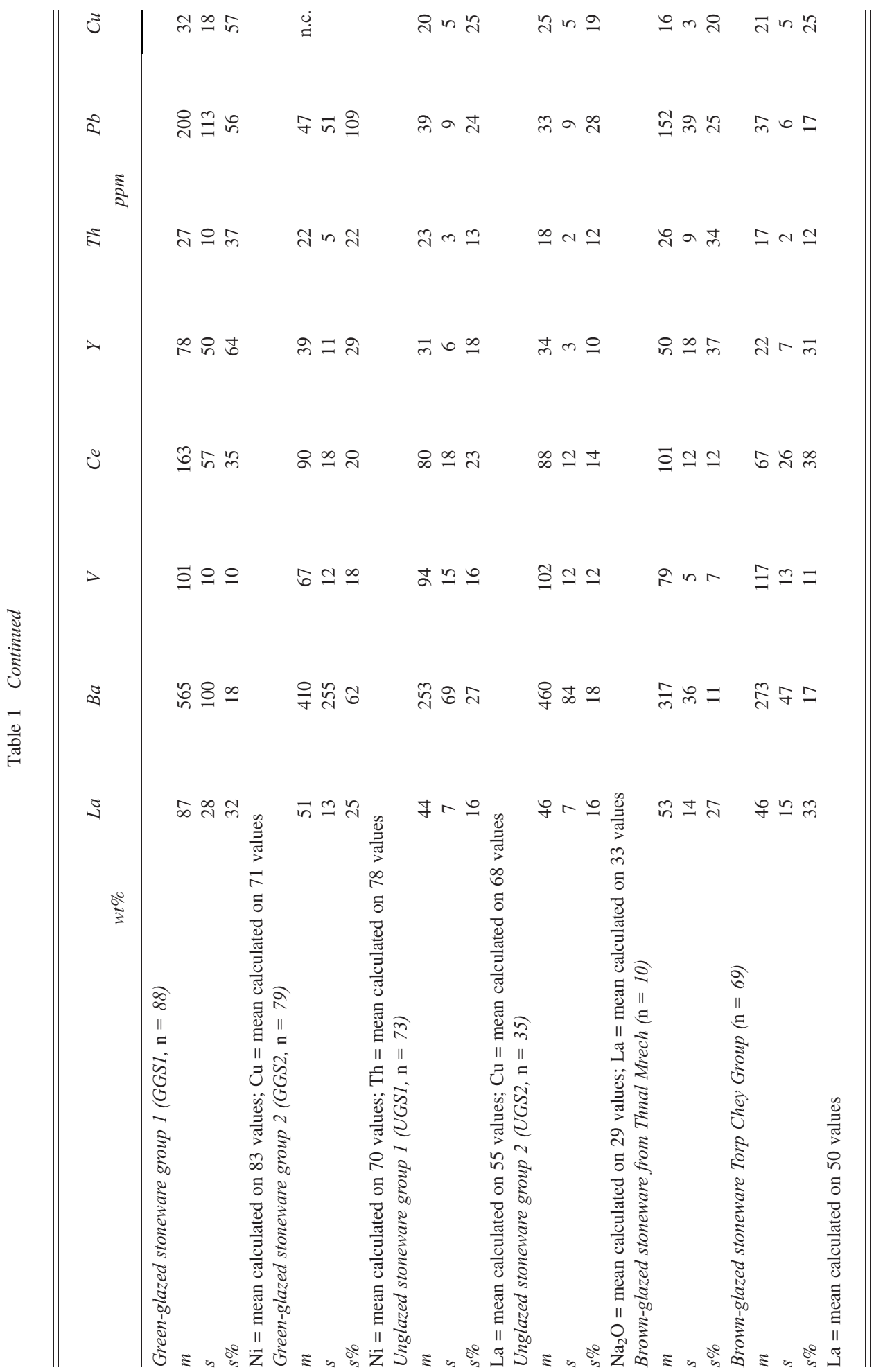




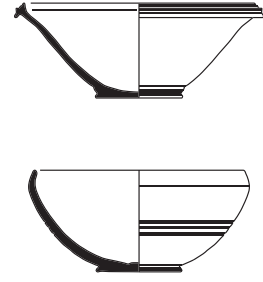

(c)
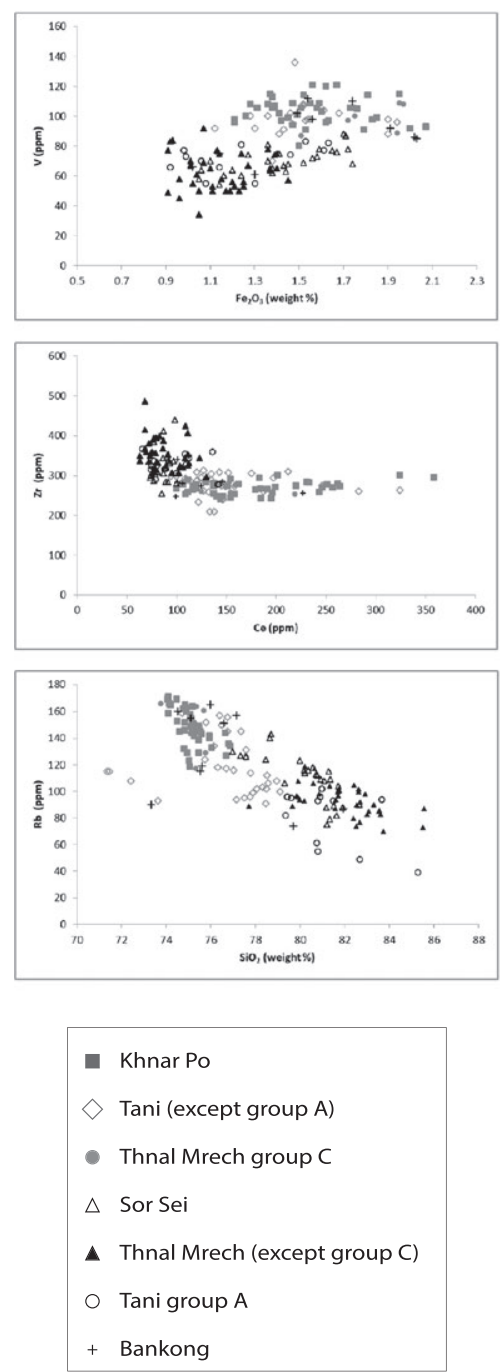

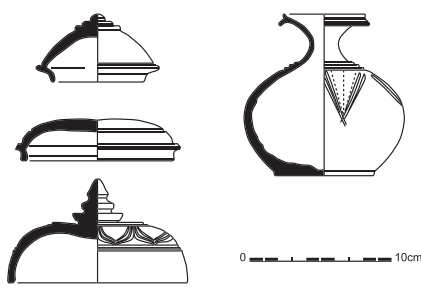

(a)

(b)

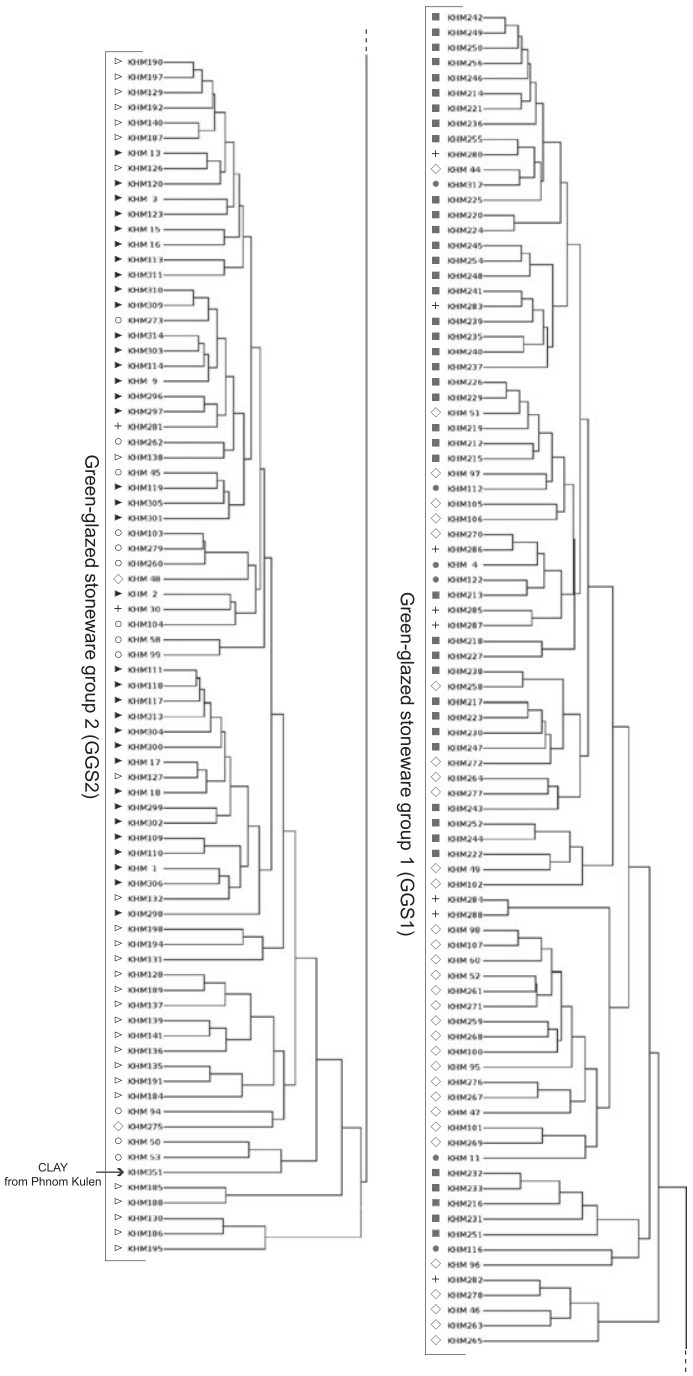

Figure 3 (a) The most important forms of green-glazed stoneware from the different kiln sites (Thnal Mrech, Khnar Po, Tani and Sor Sei); (b) dendrogram of the cluster analysis of all analysed green-glazed stoneware from Tani, Bankong, Thnal Mrech, Sor Sei and Khnar Po (calculated on 16 components); and (c) selected binary plots with all analysed samples of the green-glazed stoneware. 
by the two groups. Although collected at one kiln site, these few samples of green-glazed wares appear not to have been produced at Bankong, but imported from other kiln sites. As mentioned above, the dispersion of sherds around the kilns is quite large: this might be one reason why we find sherds not produced locally.

The groups formed on the basis of chemical resemblance can also be distinguished by their granulometry. The fabric of the pieces making up the Thnal Mrech/Sor Sei ensemble contains inclusions of various sizes (silt to coarse sand size), while the fabric of those forming the Khnar $\mathrm{Po} /$ Tani group mostly shows fine-grained inclusions (silt to fine sand size) and rare larger grains (medium sand size; Fig. 1). As mentioned above, the nature of the inclusions, mainly quartz, does not in this case contribute to the differentiation.

In the course of field prospection, clays were collected and analysed. Among these, only one clay source on Phnom Kulen could be matched chemically to the green-glazed stoneware group from Thnal Mrech and Sor Sei. It is marginally integrated into the cluster (Fig. 3, b) and its granulometry also fits with that group (Fig. 1, m). Generally, it is rare to find the clay pits exploited by the ancient potters as the geographical outlay changed over the past centuries.

In summary, the results concerning the green-glazed stoneware suggest that two groups can be distinguished and defined analytically (Thnal Mreck/Sor Sei and Tani/Khnar Po); each group is composed of most of the representatives of two kiln sites plus a subgroup from a third. We deduce that very similar kaolinitic, white-firing clays were used at all Angkorian kiln sites. Some of the chemical components that distinguish the two groups are characteristic of the clay minerals originally making up the matrix. In group 1 , the principal concerned components, alumina, potash, titanium oxide, rubidium and magnesia, show higher contents. Theoretically, the chemical composition of group 1 could therefore result from levigation of the clay used for group 2, as the levigation process increases the concentration of the clay minerals. The chemical composition points to a clay composed of kaolinite (high alumina), illite $\left(\mathrm{K}_{2} \mathrm{O}\right.$ content), chlorite ( $\mathrm{MgO}$, part of the $\left.\mathrm{Fe}_{2} \mathrm{O}_{3}\right)$ and some anatase $\left(\mathrm{TiO}_{2}\right.$ mineral) in the clay matrix and quartz as inclusions. None of the sampled clays, however, showed this exact mineralogical composition (X-ray diffraction data not shown).

Nevertheless, it is possible that the clay material used for the Khnar Po/Tani group was levigated, while that for the Thnal Mrech/Sor Sei group, very similar in grain size to some clay samples, was just homogenized before pot forming, but was not otherwise processed. As the samples collected on Khnar Po and Tani sites appeared to be older than the samples from Sor Sei and Thnal Mreck, it might then seem that, over time, potters changed their clay preparation protocols to a less time-consuming process. In order to verify this, one would require a lot of raw material, chemically close to the stoneware, and carry out experimental treatments on these samples. However, we did not find adequate outcrops of useful clays.

Other reasons could account for the chemical and granulometric differences, especially the use of clays from different sources. Geographically, the relationship between the kiln sites appears as presented in Figure 4. It suggests a geological reason for the compositional differences of the clays used, as both associated kiln sites located in close proximity to Phnom Kulen may have used the same clay pit, different from the outcrops used by the workshops situated in the plain. Indeed, clay beds located in Phnom Kulen, equivalent to those mined by the Sor Sei and Thnal Mreck potters, could have been eroded and resedimented in the plain by alluvial transport. In the course of natural sedimentation processes, occurring during/after alluvial transport, the coarsest and heaviest particles such as quartz or zircon settle and are deposited separately, similar to the levigating process realized by potters. However, we did not find this kind of fine clay deposits, enriched in clay minerals, during prospection. 


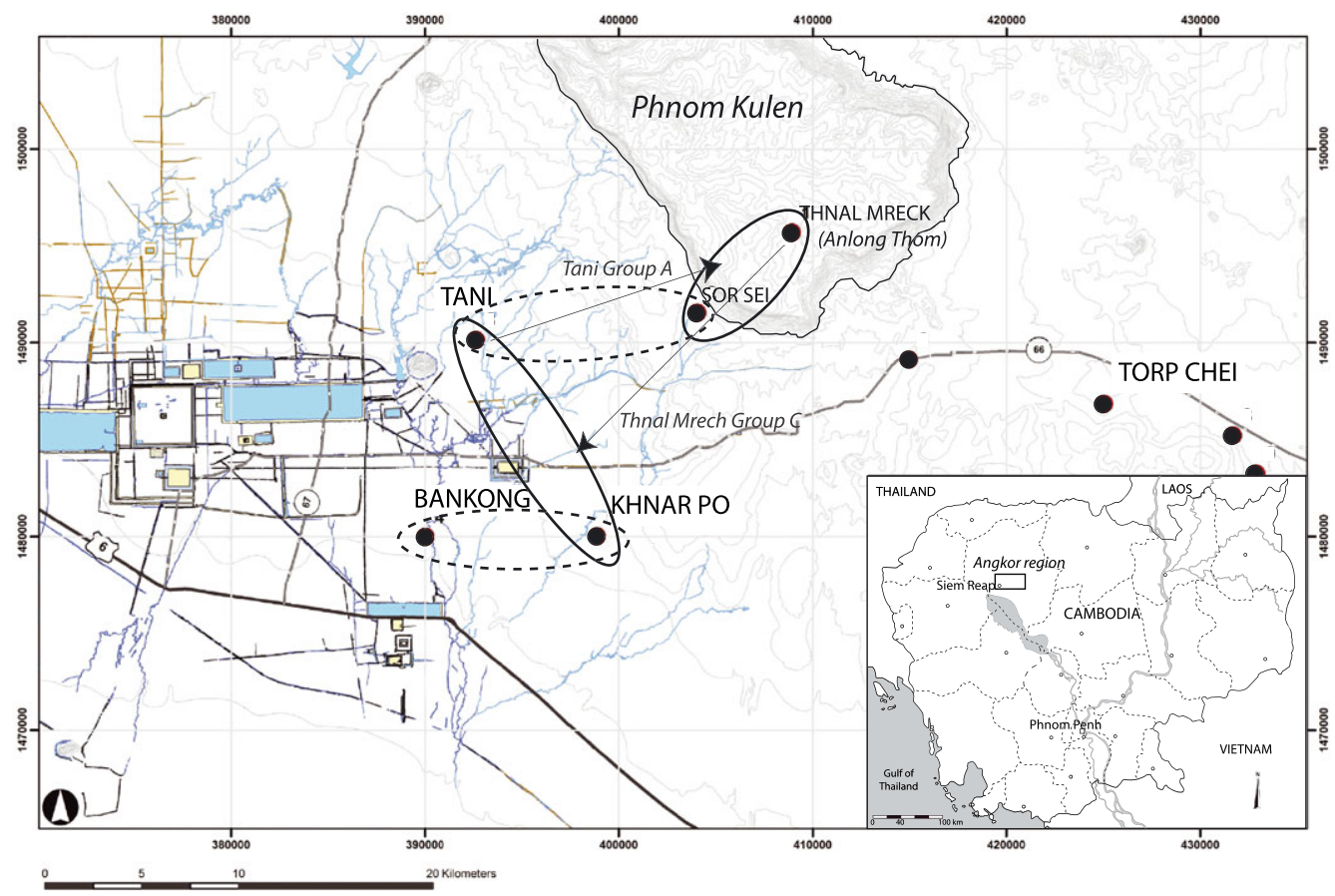

- KILN SITES OF ANGKOR REGION

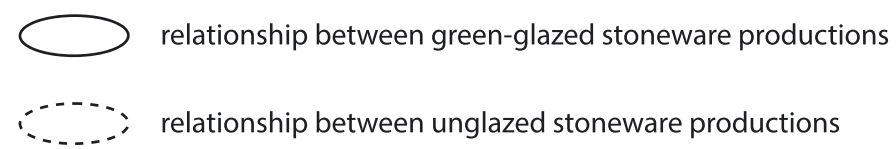

Figure 4 Relationships based on the use of similar raw material for green-glazed stoneware productions (ovals) and for unglazed stoneware productions (dotted ovals); arrows show dissident subgroups. Map background: EFEO/GAP/Jica; drawings: Socheat Chea. [Colour figure can be viewed at wileyonlinelibrary.com]

\section{Unglazed stoneware}

Analyses of this type of stoneware were carried out for four of the kiln sites: Tani, Sor Sei, Khnar Po and Bankong. At Thnal Mrech this type of ceramic was found only in very small numbers, and therefore was not analysed. The analysed sample collection comprises mainly larger bottles, jars and bowls (Fig. 5, a) (Desbat et al. 2008, 2009, 2010, 2011, 2012).

While products from Bankong and Khnar Po show light-coloured fabrics (yellow to salmoncoloured), those from Sor Sei and Tani display darker, orange to red colours (Fig. 1). Under the microscope, no obvious differences were observed apart from the colour, although Sor Sei wares appear to contain the coarsest inclusions (no petrographic analysis was carried out on ceramics from Khnar Po). Inclusions are almost exclusively quartz, along with different types of ferruginous nodules.

With the exception of a single sherd, certainly imported from the Tani kiln site, the dendrogram of the cluster analysis reflects this separation into two groups named UGS1 and UGS2 (Fig. 5, b). Samples from Khnar Po and Bankong, distinguished by a light fabric, form one cluster, and those from Tani and Sor Sei, characterized by a darker fabric, fall into the second cluster. One clay source near Bankong kiln site could be matched chemically to the first group. The 


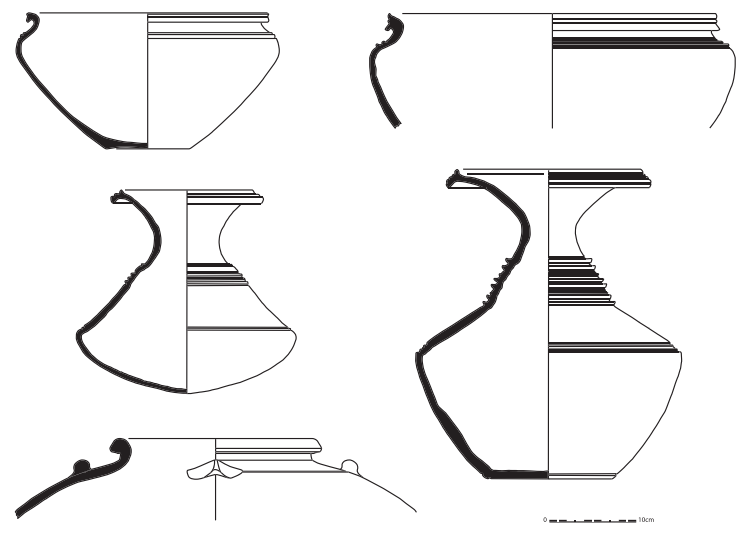

(a)
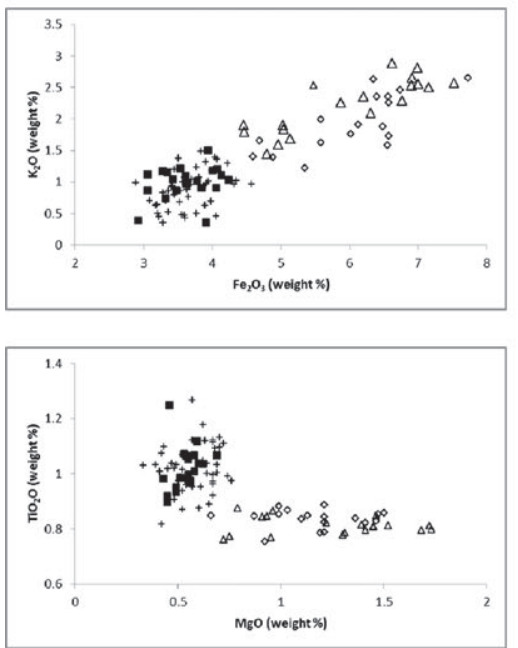

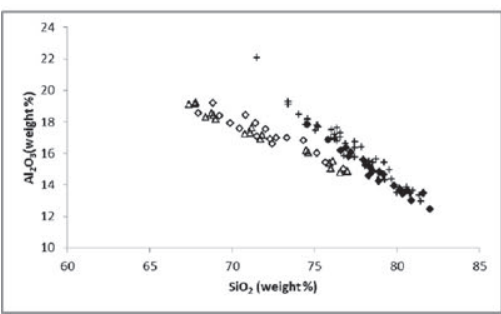

(c)

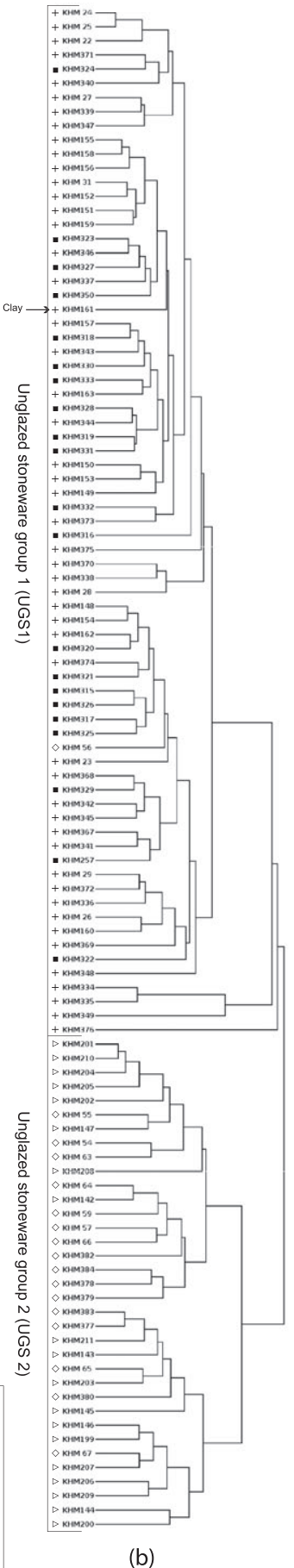

(b)

Figure 5 (a) Typical forms of unglazed stoneware from Tani, Bankong, Sor Sei and Khnar Po; (b) dendrogram of the cluster analysis of all analysed unglazed stoneware from these four kiln sites (calculated on 16 components); and (c) selected binary plots with all analysed samples of the unglazed stoneware. 
separation is justified not only on the basis of the iron content expected from the colour difference: other parameters such as potassium oxide, the correlation of alumina and silica, as well as titanium and magnesium oxides differentiate the two clusters, as demonstrated by the distribution in the binary plots of Figure 5 (c). These differences definitely point to clays from diverse outcrops and cannot be explained by changing paste preparations.

Projected on the map, the correspondences concerning the unglazed wares mark again two groups, but with different connections compared with the green-glazed ware (Fig. 4). Tani and Khnar Po are linked by the use of very similar clays for the green-glazed ware, but do not show this connection concerning unglazed stoneware. The relationships between the kiln sites, based on the use of similar raw materials, appear to be quite different for the unglazed stoneware. Currently, we are unable to propose explanations for this unexpected discrepancy.

\section{Brown-glazed stoneware}

Additionally to green-glazed ware, some brown-glazed stoneware was produced in the Thnal Mrech kilns, mainly urns and lids (Desbat et al. 2008, 2009, 2010, 2011, 2012). This brownglazed stoneware shows chemical compositions different from the green-glazed stoneware produced at the same kiln site and forms another relatively homogeneous group in terms of composition (Tables 1 and S1). This brown-glazed stoneware has slightly different stylistic characteristics from green-glazed stoneware, especially the lids with their distinctive incised decoration (Desbat et al. 2011, 6, pl. 2). It may be that they correspond to a later phase of production at Thnal Mreck. Two hypotheses could explain the unique chemical characteristics of brownglazed stoneware at this site: the rarefaction of the white clay source has resulted in the use by potters of another clay material; or, alternatively, the later production emulated the brown glaze of Buriram potters.

\section{DISCUSSION}

The main goal of the archaeometrical component of the Cerangkor Project, the creation of a reference database for stoneware produced in the Angkor region, has been successfully realized, thus providing a useful tool for provenance determination of stoneware from consumption sites in future studies. These reference groups are established for each type of stoneware produced at the kiln sites, green-glazed and unglazed stoneware. Additionally, this study has addressed several issues. From the petrographic results, we deduce that the potters of each kiln site selected different clay materials appropriate for the two types of production: a relatively pure white clay material for green-glazed stoneware and a coarser clay material with more ferruginous nodules for unglazed stoneware. The petrographic analyses proved that the differences between these two clay sources are due to different clay sources and not to different paste preparations. At Thnal Mrech, we identified an additional homogeneous group for brown-glazed stoneware, the potters selecting in this case still another clay material.

The study also proves that the green-glazed stoneware from the five kiln sites in the Angkor region show very similar compositions, indicating the procurement of clay materials from the same geological origin. Nevertheless, two groups may be distinguished thanks to the XRF analyses: a group essentially formed by the Thnal Mrech/Sor Sei kiln sites next to Phnom Kulen and the other by the Tani/Khnar Po kiln sites situated in the plain. One hypothesis for the differences found could be the levigation of the clay materials at Khnar Po and Tani. 
Two groups were also distinguished for unglazed stoneware, but the connections between kiln sites appear to be independent from the groupings among the green-glazed ware.

The possible reasons for the separation into two compositional groups are manifold, and include technical (possible levigation), geological, geographical, chronological or a combination of these factors. Slight variations in the clay-beds at different locations may explain these clusterings, and various clay sources could have been exploited by different workshops and/or during distinct time periods. Perhaps the exploitation of resources was managed independently of the pottery workshops, and the separation reflects the commercial or administrative differentiation of tasks including raw materials procurement, clay preparation and firing. These possibilities are just some ideas about how these results concerning the kiln sites could improve one's understanding of the social and economic organization of craft production during the Angkorian period.

In recent studies, the use of neutron activation analysis (NAA) has been described as the most effective technique to differentiate Angkorian kiln sites (Grave et al. 2017). Actually, the issue here is not the technique employed, but the research strategy adopted. Grave et al. studied sherds from only three of the five kilns sites of our analysis, but included sherds from Torp Chey, a production site associated with a totally different category of brown-glazed stoneware dating to a later period. They differentiated the kiln sites without taking into account the categories of stoneware produced. NAA proved valuable in distinguishing the green-glazed stoneware of Thnal Mrech from the unglazed stoneware of Tani or Bankong, but this can also be done with other techniques such as XRF or petrographic observations, as demonstrated here. For instance, the differentiation of production at Torp Chey, the kiln site located at the north-east of Siem Reap that produced mostly big brown-glazed jars (Hendrickson 2008; Ea 2013), was achieved through a visual observation of the fabric (Fig. 1: 1u). Indeed, the Cerangkor Project focuses also on this particular production of brown-glazed stoneware from a series of kiln sites situated near Torp Chey (Desbat et al. 2008, 2009, 2010, 2012). From a typological point of view, they differ significantly from the kiln sites near Angkor. The Torp Chey fabrics are characterized by big ferruginous nodules in a coarse grey paste, and they cannot be confused with the ceramics from the data set presented above. The compositions obtained with XRF also proved to be extremely different (Table 1) (Desbat et al. 2009, 2010, 2012). These analyses were elaborated in order to compare the typologically similar pottery from consumption sites. Before using complex and costly techniques to analyse ceramics, a sound typological study is indispensable. Ultimately, research must be guided by the relevant questions of specific archaeological designs, which would determine the appropriate methods and sample sizes.

\section{OUTLOOK}

To improve our knowledge about the organization of Angkorian stoneware production, the Cerangkor Project turns to other regions of the ancient Angkorian Empire where more kiln sites have been reported, some in Cambodia (Ea 2009, 2010), but especially in Buriram province in Thailand, where over 100 kiln sites have been discovered (Khwanyuen 1985, Srisuchat and Srisuchat 1989, Natthapatra 1990). Between 2015 and 2017, the Cerangkor team conducted several surveys of the Buriram kiln sites (Ban Kruat and Lahansai districts) and also at Ban Sawai (Surin province) and Ban Ya Kha (Nakhon Ratchasima province) where other kiln sites have been identified (Brown et al. 1974; Rooney and Smithies 1992). New references groups will be constituted in the near future and will be compared with those presented here. 
In light of the anticipated results, it will be possible to study the distribution on consumption sites of the different types of Angkorian stoneware produced in Siem Reap and Buriram provinces.

The exact date of the end of the production of green glaze stoneware in the Angkor region has as yet to be determined, but it is commonly thought to have occurred during the 12th century. However, from the typological study of ceramics at consumption sites, we can deduce with certainty that this production no longer existed at the end of 12 th century. At this time, all the Khmer glazed stoneware come from Buriram where kiln sites are more numerous and much larger. A first hypothesis for the shutdown of the Kulen-type stoneware would be the scarcity of the white clay required for the manufacture of green glaze stoneware. Another hypothesis would be the development of the Buriram kilns during the 11th century that led to the decline of the Angkorian kilns.

The provenance determination, based on archaeometrical analyses, of stoneware discovered on well-dated consumption sites will provide new information about the changing relationship between Angkor and its provinces. From these diffusion studies, it will be possible to gain an idea about the distribution networks of Angkorian ceramics throughout the Khmer Empire.

\section{ACKNOWLEDGEMENTS}

The authors thank the APSARA Authority, which gave the authors permission to export and analyse the samples; and special thanks to Chhay Rachna, who gave the authors the samples from the kiln site at Bankong. Some of the paper's results were presented at the European Association of Southeast Asian Archaeologists conferences in Dublin, 2012, Paris, 2015, and Poznan, 2017.

\section{REFERENCES}

Aoyagi, Y., and Sasaki, T. (eds.), 2007, The Tani kiln site in Cambodia, Sophia University, Rengo, Tokyo, Tokyo.

Aoyagi, Y., Sasaki, T., Tanaka, K., Nogami, T., Marui, M., and Sumida, T., 2000, Excavation of a Khmer ceramic kiln site: Report of the investigation of kiln B1, Tani kiln complex, Journal of khmer Studies, UDAYA, 1, $235-53$.

Aymonier, E., 1901, Les provinces Siamoises. Le Cambodge, Vol. 2, Ernest Leroux, Paris.

Baxter, M. J., 1994, Exploratory multivariate analysis in archaeology, Edinburgh University Press, Edinburgh.

Brown, R., Childress, V., and Gluckman, M., 1974, A Khmer kiln site-Surin Province, Journal of The Siam Society, 62(2), 239-52.

Chhay, R., Heng, P., and Chhay, V., 2013, Khmer Ceramic Technology, A Case Study from Thnal Mrech Kiln Site, Phnom Kulen, 12th International Conference of European Association of Archaeologists, Leiden, 1-5 sept. 2008, Materializing Southeast Asia's past: selected papers from the 12th International Conference of the European Association of Southeast Asian Archaeologists, Volume 2, Chap. 14, Singapore 2013, 179-95-.

Courbin, P., 1988, La fouille du Sras Srang, 22, EFEO, Paris.

Desbat, A., 2007, L'étude du mobilier céramique, in Pottier C. ed., Mission archéologique franco-khmère Sur l'aménagement du territoire angkorien (Mafkata) Campagne 2008, rapport.

Desbat, A., 2011, Pour Une révision de la chronologie des grès Khmers, Aséanie, 27, 11-34.

Desbat, A., (dir.) with the collaboration of Bernet, A., Chea, S., Choi, M., Hong, R., Thirion-Merle, V., Phon, K., Pottier, Ch., Soutif, D., Thierrin-Michael, G., and Sothearith, Y., 2013, Recherches sur les ateliers de potiers angkoriens, rapport programme Cerangkor 2013, MAE, 73p.

Desbat, A., (dir.) with the collaboration of Bernet, A., Chea, S., Choi, M., Hong, R., Thirion-Merle, V., Pottier, Ch., and Soutif, D., 2014, Recherches sur les ateliers de potiers angkoriens, rapport programme Cerangkor 2014, MAE, 54p.

Desbat, A., (dir) with the collaboration of a. Bernet, A., Chea, S., Choi, M., Hong, R., Thirion-Merle, V., Pottier, Ch., and Soutif, D., 2015, Recherches sur les ateliers de potiers angkoriens, rapport programme Cerangkor 2015, MAE, 80p.

Desbat, A., (dir.) with the collaboration of Bernet, A., Beukin, A., Laduron, D., LLopis, E., Pottier, Ch., Thirion-Merle, V., Chea, S., Hong, R., Soutif, D., Thierrin-Michael, G., Uong, S., and Vierstraete, A., 2010, Recherches sur les ateliers de potiers angkoriens, rapport programme Cerangkor 2010, MAE, 71p. 
Desbat, A., (dir.) with the collaboration of Bernet, A., Beukin, A., Laduron, D., LLopis, E., Pottier, Ch., Thirion-Merle, V., Chea, S., Udomrengsey, L., Uong, S., and Vierstraete, A., 2009, Recherches sur les ateliers de potiers angkoriens, rapport programme Cerangkor 2009, MAE, 48p.

Desbat, A., (dir.) with the collaboration of Bernet, A., Laduron, D., LLopis, E., Pottier, Ch., Thirion-Merle, V., Chea, S., Hong, R., Soutif, D., Thierrin-Michael, G., and Vicheth, T., 2011, Recherches sur les ateliers de potiers angkoriens, rapport programme Cerangkor 2011, MAE, 117p.

Desbat, A., (dir.) with the collaboration of Bernet, A., Pottier, Ch., Thirion-Merle, V., Chea, S., Hong, R., Soutif, D., Thierrin-Michael, G., Phon, K., and Sothearith, Y., 2012, Recherches sur les ateliers de potiers angkoriens, rapport programme Cerangkor 2012, MAE, 85p.

Desbat, A., (dir.) with the collaboration of Beukin, A., Laduron, D., LLopis, E., Pottier, Ch., Schmitt, A., Chea, S., Uong, S., and Vierstraete, A., 2008, Recherches sur les ateliers de potiers angkoriens, rapport programme Cerangkor 2008, MAE, 44p.

Ea, D., 2009, New data on the distribution of Khmer ceramic kilns and the study of ceramics, in Scientific research on historic Asian ceramics: Proceedings of the fourth Forbes symposium at the Freer Gallery of art (eds. B. McCarthy, E. S. Chase, L. A. Cort, J. G. Douglas, and P. Jett), 207-14, Archetype Publications with the Freer Gallery of Art, Washington DC 2007.

Ea, D., 2010, Angkorian stoneware ceramics: The evolution of kiln structure and ceramic typology, PhD dissertation, Osaka Othani University.

Ea, D., 2013, Angkorian stoneware ceramics along the east road from Angkor to Bakan at Torp Chey village, Journal of Khmer Studies, Udaya, 11, 59-98.

Grave, P., Stark, M., Ea, D., Kealhofer, L., Tan, B. S., and Tin, T., 2017, Differentiating khmer stoneware production: An NAA pilot study from Siem Reap Province, Cambodia, Archaeometry, 59(1), 13-24.

Groslier, B.-Ph., 1954, Fouilles du palais royal d'Angkor Thom, Proceedings of the twenty-third international congress of the orientalists, Cambridge, London, 228-9.

Groslier, B.-Ph., 1964, Rapport de la conservation d'Angkor (RCA), Banteay Kdei - Sras Srang, esplanade occidentale, Archives de l'Ecole française d'Extrême Orient, Paris.

Hein, D., Cort, L., and Ea, D., 2013, in The Chong Samrong kiln site in Cambodia: Report on a training excavation (ed. L. A. Cort), Freer Gallery of Art, Arthur Sackler Gallery, Smithsonian Institution, Washington DC.

Hendrickson, M., 2008, New evidence of brown glaze stoneware kilns along the east road from Angkor, Indo-Pacific Prehistory Association Bulletin, 28, 52-6.

Hirooka, K., Nakamura, H., Inoue, Y., Ikeda, Y., and Sugiyama, H., 2009, Research result from natural science analysis archaeological and terrestrial research on Khmer ceramics kilns Cambodia, Khnar Po B1 kiln, final report of excavation, Osaka-Otani University Museum Report 55.

Khwanyuen, S., 1985, The excavation of Baranae kiln site, Thailand, 137-168, in Technical Workshop on Ceramics (TW4): Final Report, Bangkok: SPAFA.

Maggetti, M., Schubiger, A., and Wyttenbach, A., 1981, Homogenität archäologischer keramischer Objekte, Teil II: Ergebnisse der Neutronenaktivierungsanalyse, Archäologie und Naturwissenschaften, 2, 21-32.

Marriner, G. P., Grave, P., Kealhofer, L., Stark, M. T., Ea, D., Chhay, R., Phon, K., and Boun Suy, T., 2018, New dates for old kilns: A revised radiocarbon chronology of stoneware production for Angkorian Cambodia, Radiocarbon, 60(3), 901-24.

Miksic, J., and Chhay, R., 2010, Khmer potters emerge from the shadows: Thnal Mrech and Bangkong kiln sites, SPFA Journal, 20, 5-14.

Miksic, J., Chhay, R., Heng, P., and Chhay, V., 2008, Archaeological report regarding the assessment at the Thnal Mrech kiln site TMK 02, Anlong Thom, Phnom Kulen, Cambodia, Report for APSARA.

Nakamura, H., Ikeda, M., Hirooka, K., Sugiyama, H., Mitsuji, T., Ea, D., Sato, Y., Sovannara, S. K., and Aki, M., 2011, Bakong kiln ruins 6A B kiln traces: Excavation report. Osaka Otani University Museum Report. Osaka: Osaka Otani University Museum.

Natthapatra, C., 1990, Ancient kiln sites in Buriram Province, northeastern Thailand, in Ancient ceramic kiln Technology in Asia (ed. C.-m. Ho), 230-43, Centre of Asian Studies, university of Hong Kong, Hong Kong.

Picon, M., 1984, Le traitement des données d'analyses, in Datation-caractérisation des céramiques anciennes (eds. T. Hackens and M. Schvoerer), 379-99, PACT 10.

Pottier, Ch., and Desbat, A., 2016, (dir.), with the collaboration of Bernet, A., Choi, M., Mc Clintock, T., Hong, R., Thirion-Merle, V., Nauleau, N., San, K., Soutif, D., Van, S., MAFKATA-CERANGKOR, Campagne 2016, Rapport, MAE, $118 \mathrm{p}$.

Pottier, Ch., and Desbat, A., 2017, (dir.), with the collaboration of Ly, V., Thirion-Merle, V., Thierrin-Michael, G., Deverne, S., Ben Amara, A., Nauleau, N., Choi, M., Hong, R., Lao, J., Bernet, A., MAFKATA-CERANGKOR, Campagne 2017, Rapport, MAE, 156p. 
Rooney, D. F., and Smithies, M., 1992, The Khmer kilns of ban Ya Kha, Journal of Siam Society, 85(1 and 2), 151-9. Srisuchat, T., and Srisuchat, A., 1989, Introducing Buriram ceramics and kilns, The Silpakorn Journal, 33(2), 42-52.

Sugiyama, H., 2008, The Excavation Research of Sar Sei kiln, research on middle age of archaeological site: Japanese town in Cambodia, finance by Ministry of Education, culture, sports, science and technology, Grants-in-aid for scientific research, Grant-in-aid for special purpose, Subject No. 19900125.

Sugiyama, H., Sato, Y., and Tabata, Y., 2017, Report on the Archaeological Excavation of Veal Svay Kiln $N^{\circ} 1$, Nara National Research Institute for cultural properties, APSARA Authority, Nara City, Japan, 31 p.

Tabata, Y., 2005, Stoneware ceramics production in the Angkor area in Cambodia: A comparative study of artifacts from the Tani, Anlong Thom and Sar Sei kilns, Journal of Sophia Asian Studies, 23, 7-36.

Tabata, Y., and Chhay, V., 2007, Preliminary report of the excavation of the Anlong Thom kiln site, Cambodia, Journal of Southeast Asian Archaeology, 27, 63-9.

Tabata, Y., Sato, Y., Sok, K. S., and Sugiyama, H., 2015, Preliminary Report of the Excavation of the Veal Svay kiln site in Cambodia, Febr. 2013-Dec. 2013, Bulletin of the Graduate Division of Lettres, Arts and Sciences of Waseda University, 60 IV, 57-68.

Thirion-Merle, V., 2014, Spectrométrie de fluorescence X, In Circulation et provenance des matériaux dans les sociétés anciennes, Dir. Dillmann P et Bellot-Gurlet L, Collection « Sciences Archéologiques », 2014, 291-7.

Tin, T., 2003, Khmer ceramics: A case of study of the ceramics from the Sarsey kiln complex in the Angkor area, master degree of professional study of archaeology, Sophia University, Tokyo, 2003.

Waksman, S.Y., 2014, Etudes de provenance de céramiques, In Circulation et provenance des matériaux dans les sociétés anciennes, Dir. Dillmann P et Bellot-Gurlet L, Collection «Sciences Archéologiques », 2014, 195-215

Yamamoto, N., 2011, Link between archaeological observation and paste analysis of unearthed khmer pottery from Bayon southern library and the lower layers, chapter 6, in Archaeological study on the Bayon complex, 266-72.

\section{SUPPORTING INFORMATION}

Additional supporting information may be found online in the Supporting Information section at the end of the article.

Table S1. Compositional data of the Khmer stoneware generated by the Cerangkor Project. The data are presented, by stoneware category, in the order of each dendrogram of figures $3 \mathrm{~b}$ and $5 \mathrm{~b}$. (Major and minor elements are given in oxides weight \%, trace elements in parts per million). 